\title{
Distinct phenotypes distinguish the molecular classes of Angelman syndrome
} A C Lossie, M M Whitney, D Amidon, H J Dong, P Chen, D Theriaque, A Hutson,
R D Nicholls, R T Zori, C A Williams, D J Driscoll

\section{Abstract}

Background-Angelman syndrome (AS) is a severe neurobehavioural disorder caused by defects in the maternally derived imprinted domain located on 15q11q13. Most patients acquire AS by one of five mechanisms: (1) a large interstitial deletion of 15q11-q13; (2) paternal uniparental disomy (UPD) of chromosome 15; (3) an imprinting defect (ID); (4) a mutation in the $\mathrm{E} 3$ ubiquitin protein ligase gene (UBE3A); or (5) unidentified mechanism(s). All classical patients from these classes exhibit four cardinal features, including severe developmental delay and/or mental retardation, profound speech impairment, a movement and balance disorder, and AS specific behaviour typified by an easily excitable personality addition, patients can display other characteristics, including microcephaly, hypopigmentation, and seizures.

Florida, Gainesville,

FL, USA

A C Lossie

D J Driscoll

Division of

Biostatistics,

Department of

Statistics, University of

Florida, Gainesville,

FL, USA

P Chen

A Hutson

GCRC, University of Florida, Gainesville, FL, USA

D Theriaque

A Hutson

Center for

Neurobiology and

Behavior, Department of Psychiatry,

University of

Pennsylvania,

Philadelphia, PA, USA

R D Nicholls

Correspondence to: Dr Driscoll, Pediatric Genetics, Box 100296 ,

University of Florida College of Medicine, Gainesville, FL

32610-0296, USA,

driscdi@peds.ufl.edu

*Present address:

Department of Molecular

and Human Genetics, Baylor

College of Medicine,

Houston, TX 77030, USA

Revised version received

14 August 2001

Accepted for publication

26 August 2001

\section{Methods-We restricted the present study} to 104 patients (93 families) with a classical AS phenotype. All of our patients were evaluated for 22 clinical variables including growth parameters, acquisition of motor skills, and history of seizures. In addition, molecular and cytogenetic analyses were used to assign a molecular class (I-V) to each patient for genotypephenotype correlations.

Results-In our patient repository, $22 \%$ of our families had normal DNA methylation analyses along 15q11-q13. Of these, $44 \%$ of sporadic patients had mutations within $U B E 3 A$, the largest percentage found to date. Our data indicate that the five molecular classes can be divided into four phenotypic groups: deletions, UPD and ID patients, $U B E 3 A$ mutation patients, and subjects with unknown aetiology. Deletion patients are the most severely affected, while UPD and ID patients are the least. Differences in body mass index, head circumference, and seizure activity are the most pronounced among the classes.

Conclusions-Clinically, we were unable to distinguish between UPD and ID patients, suggesting that 15q11-q13 contains the only significant maternally expressed imprinted genes on chromosome 15.

(F Med Genet 2001;38:834-845)

Keywords: Angelman syndrome; genotype-phenotype correlations; DNA methylation; 15q11-q13
Angelman syndrome (AS) (MIM 105830) is a severe neurobehavioural disorder that occurs with a frequency of $\sim 1 / 15000 .{ }^{1}$ First documented by Dr Harry Angelman, ${ }^{2}$ AS is now diagnosed by four cardinal features: (1) severe developmental delay; (2) profound speech impairment; (3) a movement and balance disorder; and (4) a characteristic behavioural profile that includes frequent, inappropriate laughter, a happy affect, and an easily excitable personality. Other common features include seizures, microcephaly, abnormal EEG patterns, sleep disturbances, hypopigmentation, and strabismus. ${ }^{34}$

Four major molecular mechanisms are known to cause Angelman syndrome. Most patients with AS (class I, deletion) have an $\sim 4$ $\mathrm{Mb}$ maternally derived interstitial deletion of 15q11-q13. Some patients (class II, UPD) have paternal uniparental disomy of the entire chromosome 15, while others (class III, ID) show defects in the imprinting process. In addition, intragenic mutations in the E6AP-E3 ubiquitin protein ligase gene (UBE3A) occur in several subjects with AS (class IV, $U B E 3 A$ ). Furthermore, a diagnosis of Angelman syndrome has been established in a large number of patients who have no known molecular lesion. These patients (class V) comprise a fifth group of subjects with AS. Although patients in classes I-III can be easily diagnosed by DNA methylation analyses along the 15q11-q13 imprinted domain, ${ }^{5}$ subjects from classes IV and $\mathrm{V}$ show normal DNA methylation in this region.

The discovery of maternally inherited mutations in several patients with normal DNA methylation along 15q11-q13 first established a role for $U B E 3 A$ in the aetiology of $\mathrm{AS}^{6}{ }^{7}$ Subsequent studies identified an overall $U B E 3 A$ mutation rate of $14-38 \%$ in sporadic patients. $^{8-12}$ Although cell lines from subjects with AS failed to show imprinted expression of $U B E 3 A,{ }^{13}$ demonstration of brain specific imprinting by RT-PCR in the human confirmed the role of $U B E 3 A$ in the pathogenesis of $\mathrm{AS}^{14}$

Phenotypic analyses of several deletion (class I) patients have generated a profile considered by many to typify the classical AS phenotype. These patients showed a high incidence of severe, early onset seizures, microcephaly, and hypopigmentation. ${ }^{15}{ }^{16}$ However, patients from classes II and III often exhibited atypical features that ameliorated the classical phenotype. Patients with UPD and imprinting defects (ID) were less likely to present with 
Table 1 BESS-T primers

\begin{tabular}{|c|c|c|c|c|}
\hline Exon & $\operatorname{Primer}\left(5^{\prime} \rightarrow 3^{\prime}\right)$ & Direction & Location & Size $(b p)$ \\
\hline 6 & $\begin{array}{l}\text { TGCCAGCAGGTTTATTTTT } \\
\text { ACCAGCCTTGTGGGTAAG }\end{array}$ & $\begin{array}{l}\text { Forward } \\
\text { Reverse }\end{array}$ & $\begin{array}{l}\text { Exon } \\
\text { Exon }\end{array}$ & 187 \\
\hline 7 & $\begin{array}{l}\text { GGAGAACCTCAGTCTGACGAC } \\
\text { ATTCGGCTAGCTTCAATGTC }\end{array}$ & $\begin{array}{l}\text { Forward } \\
\text { Reverse }\end{array}$ & $\begin{array}{l}\text { Exon } \\
\text { Exon }\end{array}$ & 38 \\
\hline 8 & $\begin{array}{l}\text { GCAGCTGCAAAGCATCTAAT } \\
\text { TCAATTCTAGCGCCTTTCTT }\end{array}$ & $\begin{array}{l}\text { Forward } \\
\text { Reverse }\end{array}$ & $\begin{array}{l}\text { Exon } \\
\text { Exon }\end{array}$ & 284 \\
\hline $10^{\star}$ & $\begin{array}{l}\text { GCAATCATCTTCTTTTCATGTT } \\
\text { CGACACCATAATCACATTAC }\end{array}$ & $\begin{array}{l}\text { Forward } \\
\text { Reverse }\end{array}$ & $\begin{array}{l}\text { Intron } \\
\text { Intron }\end{array}$ & 194 \\
\hline 11 & $\begin{array}{l}\text { TGTTCACATACGATGAATCTACA } \\
\text { CTCCCAAGTCACGAAAAGTT }\end{array}$ & $\begin{array}{l}\text { Forward } \\
\text { Reverse }\end{array}$ & $\begin{array}{l}\text { Exon } \\
\text { Exon }\end{array}$ & 192 \\
\hline 12 & $\begin{array}{l}\text { TCAGAGTTTAAAAGATTTATTGGA } \\
\text { TCCTGTTTTCATTTGTAATTGG }\end{array}$ & $\begin{array}{l}\text { Forward } \\
\text { Reverse }\end{array}$ & $\begin{array}{l}\text { Exon } \\
\text { Exon }\end{array}$ & 155 \\
\hline 13 & $\begin{array}{l}\text { GAATTTGTCAATCTTTATTCTGACT } \\
\text { CGGCTTCCACATATAAGCA }\end{array}$ & $\begin{array}{l}\text { Forward } \\
\text { Reverse }\end{array}$ & $\begin{array}{l}\text { Exon } \\
\text { Exon }\end{array}$ & 155 \\
\hline 14 & $\begin{array}{l}\text { AGATTTCCAAGCACTAGAAGAAA } \\
\text { AATCAGAACAGAGTCCCTGG }\end{array}$ & $\begin{array}{l}\text { Forward } \\
\text { Reverse }\end{array}$ & $\begin{array}{l}\text { Exon } \\
\text { Exon }\end{array}$ & 67 \\
\hline 15 & $\begin{array}{l}\text { GTTCTGGGAAATCGTTCATT } \\
\text { CTGTGTCTGGGCCATTTT }\end{array}$ & $\begin{array}{l}\text { Forward } \\
\text { Reverse }\end{array}$ & $\begin{array}{l}\text { Exon } \\
\text { Exon }\end{array}$ & 137 \\
\hline $16^{\star}$ & $\begin{array}{l}\text { ACCATGACTTACAGTTTTCCT } \\
\text { TGGGACACTATCACCACCAA }\end{array}$ & $\begin{array}{l}\text { Forward } \\
\text { Reverse }\end{array}$ & $\begin{array}{l}\text { Intron } \\
\text { Intron }\end{array}$ & 189 \\
\hline
\end{tabular}

${ }^{\star}$ Kishino et al. ${ }^{6}$ mutations in $U B E 3 A$ do not account for all patients with normal DNA methylation along the AS/PWS imprinted domain, and examine alternative mechanisms for the aetiology of AS in class $\mathrm{V}$ patients. In addition, we present the first comprehensive analysis of genotypephenotype correlations among all five molecular classes of AS and show significant differences among the five classes in growth parameters, achievement of developmental milestones, as well as severity, frequency, and onset of seizures.

\section{Materials and methods \\ PATIENT REPOSITORY \\ Clinical definition of $A S$}

Over the last 11 years, we have accumulated a large AS repository totalling 146 patients from 134 Angelman families. Each of our patients was extensively examined by clinical geneticists at the University of Florida (UF). Before laboratory testing, each patient was evaluated for 22 distinct criteria and given an AS rating of 1-5 based on clinical impression. We restricted this study to the $104 / 146$ patients (93 families) who had an AS clinical score of 1 or 2 . Patients who scored 1 showed an absolutely "classical" phenotype in every aspect. A score of 2 meant that the patient was fairly classical, but showed one or two features (for example, mild or absent seizures or obesity) that were atypical for AS. However, these patients were extremely likely to have AS, since they fulfilled all of the four main AS criteria, ${ }^{34}$ including the "AS specific" behaviour. The remaining 42 "ASlike" patients, all of whom had normal laboratory testing (DNA methylation, DNA polymorphism, and cytogenetic analyses) within 15q11-q13, exhibited some but not all of the four cardinal features of AS and were excluded from further investigation for the purposes of this study. Blood and tissue were procured with

Table 2 Sequencing primers

\begin{tabular}{|c|c|c|c|c|}
\hline Exon & Primer $\left(5^{\prime} \rightarrow 3^{\prime}\right)$ & Direction & Location & Size $(b p)$ \\
\hline 7 & $\begin{array}{l}\text { TATGGCCACCTGATCTGAC } \\
\text { TTCCTATCTCCCATTTACTGC }\end{array}$ & $\begin{array}{l}\text { Forward } \\
\text { Reverse }\end{array}$ & $\begin{array}{l}\text { Intron } \\
\text { Intron }\end{array}$ & 345 \\
\hline \multirow[t]{2}{*}{8} & $\begin{array}{l}\text { GCTTGACTAACTTTTGCCTTG } \\
\text { ATCTCCCACATGGTTTTCAG }\end{array}$ & $\begin{array}{l}\text { Forward } \\
\text { Reverse }\end{array}$ & $\begin{array}{l}\text { Intron } \\
\text { Intron }\end{array}$ & 443 \\
\hline & $\begin{array}{l}\text { GCAGCTGCAAAGCATCTAAT } \\
\text { TCAATTCTAGCGCCTTTCTT }\end{array}$ & $\begin{array}{l}\text { Forward } \\
\text { Reverse }\end{array}$ & $\begin{array}{l}\text { Exon } \\
\text { Exon }\end{array}$ & \\
\hline \multirow[t]{2}{*}{9} & $\begin{array}{l}\text { AACAGCTATGACCATGCAACAGAGTAAACATACATATT* } \\
\text { GTAAAACGACGGCCAGTCACTGAACTGTATCAT }{ }^{\star}\end{array}$ & $\begin{array}{l}\text { Forward } \\
\text { Reverse }\end{array}$ & $\begin{array}{l}\text { Intron } \\
\text { Intron }\end{array}$ & 1401 \\
\hline & $\begin{array}{l}\text { ATTAGGCCCTGATGATGTGT } \\
\text { CCAGATATTCAGGACTGTGGA }\end{array}$ & $\begin{array}{l}\text { Forward } \\
\text { Reverse }\end{array}$ & $\begin{array}{l}\text { Exon } \\
\text { Exon }\end{array}$ & \\
\hline 10 & $\begin{array}{l}\text { TTGTTTCCTAATCCTACTCCTTG } \\
\text { ACCAAATCCTTCTTTTGCTG }\end{array}$ & $\begin{array}{l}\text { Forward } \\
\text { Reverse }\end{array}$ & $\begin{array}{l}\text { Intron } \\
\text { Intron }\end{array}$ & 352 \\
\hline 11 & $\begin{array}{l}\text { GGACATTGTTTTCTCAAGTGC } \\
\text { TAAAAATGTCCCCCTTTGAG }\end{array}$ & $\begin{array}{l}\text { Forward } \\
\text { Reverse }\end{array}$ & $\begin{array}{l}\text { Intron } \\
\text { Intron }\end{array}$ & 559 \\
\hline 12 & $\begin{array}{l}\text { TGTTGTATTTTGTAGTTCTATGG } \dagger \\
\text { TTAATGAAGAGACAAAATGTGAC } \dagger\end{array}$ & $\begin{array}{l}\text { Forward } \\
\text { Reverse }\end{array}$ & $\begin{array}{l}\text { Intron } \\
\text { Intron }\end{array}$ & 257 \\
\hline \multirow[t]{2}{*}{$13 / 14$} & $\begin{array}{l}\text { GAAGTTCTTGTGATTAATGT } \dagger \\
\text { CCCTTTGGTGAATCAAATCTTCC } \dagger\end{array}$ & $\begin{array}{l}\text { Forward } \\
\text { Reverse }\end{array}$ & $\begin{array}{l}\text { Intron } \\
\text { Intron }\end{array}$ & 404 \\
\hline & $\begin{array}{l}\text { GAATTTGTCAATCTTTATTCTGACT } \\
\text { AATCAGAACAGAGTCCCTGG }\end{array}$ & $\begin{array}{l}\text { Forward } \\
\text { Reverse }\end{array}$ & $\begin{array}{l}\text { Exon } \\
\text { Exon }\end{array}$ & \\
\hline 15 & $\begin{array}{l}\text { TTCAGGATAAATTTGCTTGG } \\
\text { AAAATCACGAATGTGCTCAG }\end{array}$ & $\begin{array}{l}\text { Forward } \\
\text { Reverse }\end{array}$ & $\begin{array}{l}\text { Intron } \\
\text { Intron }\end{array}$ & 416 \\
\hline
\end{tabular}

${ }^{\star}$ Matsuura et al. ${ }^{7}$

†Malzac et al. ${ }^{8}$ 
Table 3 Molecular classes of Angelman syndrome

\begin{tabular}{llcccr}
\hline Class & Molecular defect & Families & $\%$ & Patients & $\%$ \\
\hline I & 15q11-13 deletion & 63 & 68 & 64 & 61 \\
II & Uniparental disomy (UPD) & 7 & 7 & 7 & 7 \\
III & Imprinting defect (ID) & 3 & 3 & 7 & 7 \\
IV & UBE3A mutation & 10 & 11 & 15 & 14 \\
V & Unknown & 10 & 11 & 11 & 11 \\
\hline
\end{tabular}

the approval of the families and the University of Florida Institutional Review Board.

Molecular diagnostics

Once a clinical diagnosis of AS was determined, the patient and family members were analysed by both molecular and cytogenetic tests in order to place each patient into the appropriate molecular class. Patients in classes I-III had uniparental DNA methylation at several loci along 15q11-q13, including $M K R N 3$ (formerly ZNF127), PW71, and 5' SNURF$S N R P N$, while patients from classes IV and V showed normal biparental methylation at these loci. ${ }^{23-28}$ DNA dosing, ${ }^{29}$ high resolution chromosome and fluorescence in situ hybridisation (FISH) studies detected patients with large interstitial deletions (class I), while microsatellite and RFLP analyses separated patients in class II from those in class III. ${ }^{30}{ }^{31}$ Patients with normal DNA methylation were then tested for $U B E 3 A$ mutations by a combination of Southern blot, BESS-T scan, and direct sequence analyses. Patients with intragenic UBE3A mutations were placed into class IV, while those with no detectable chromosome 15 abnormalities were put into class $\mathrm{V}$.
Seizure criteria

According to our definitions, severe seizures occurred when at least two drugs were administered for epileptic episodes. When one anticonvulsant effectively controlled grand mal seizure activity, patients were considered to have moderate seizures. Mild seizures were defined by very rare grand mal, petit mal, or multiple febrile seizures. Patients with fewer than four febrile or a complete absence of seizures were considered to have no history of seizure activity.

\section{SOUTHERN ANALYSIS}

Southern blots were done according to standard conditions. ${ }^{32}$ Patients were examined with genomic probes from the 5 ' end of $U B E 3 A$, as well as cDNA probes that covered exons 3-16. Genomic probes were generated by restriction digestion of cosmids 24 and $34 .^{25}$ cDNA probes were amplified using previously published primers for exons 3-97 and exons $9-16 .^{6}{ }^{7}$ DNA methylation analyses of $U B E 3 A$ were performed by hybridisation with a $2.7 \mathrm{~kb}$ $U B E 3 A \mathrm{CpG}$ island probe, which was generated by EcoRI to NotI digestion of cosmid 34.

\section{METHYLATION SPECIFIC PCR}

Sodium bisulphite treatment of genomic DNA and subsequent methylation analysis of SNRPN was done according to established protocols. $^{32}{ }^{33}$ Two sets of primers were designed to assess the methylation status of both NotI sites in the UBE3A CpG island. At the proximal end of the $\mathrm{CpG}$ island (more $5^{\prime}$ ), the

A

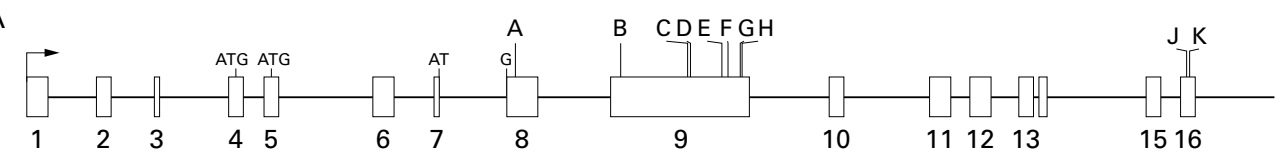

B

\begin{tabular}{cllll}
\hline Site & $\begin{array}{c}\text { Gene } \\
\text { mutation }\end{array}$ & Outcome & Inheritance & Patient \\
\hline $\mathrm{A}^{7}$ & G648A & C21Y & Maternal & AS179P \\
$\mathrm{B}^{9}$ & $980 \mathrm{del} 2$ & Frameshift & Maternal & AS181P1 \\
$\mathrm{B}$ & $980 \mathrm{del} 2$ & Frameshift & Maternal & AS181P2 \\
$\mathrm{C}^{8}$ & $1522 \mathrm{del} 2$ & Frameshift & Maternal & AS180P1 \\
$\mathrm{C}$ & $1522 \mathrm{del} 2$ & Frameshift & Maternal & AS180P2 \\
$\mathrm{D}^{9}$ & $1552 \mathrm{del} \mathrm{A}$ & Frameshift & De novo & AS106P \\
$\mathrm{E}^{7}$ & C1835T & R417X & De novo & AS178P \\
$\mathrm{F}$ & $1930 \mathrm{del} 2$ & Frameshift & Maternal & AS141P \\
$\mathrm{G}^{8}$ & C2030T & R482X & De novo & AS194P \\
$\mathrm{H}$ & A2033T & R483X & Maternal & AS169P1 \\
$\mathrm{H}$ & A2033T & R483X & Maternal & AS169P2 \\
$\mathrm{H}$ & A2033T & R483X & Maternal & AS169P3 \\
$\mathrm{H}$ & A2033T & R483X & Maternal & AS169P4 \\
$\mathrm{J}$ & 3092 del A & Frameshift & De novo & AS101P \\
$\mathrm{K}$ & 3093 del 4 & Frameshift & De novo & AS152P \\
\hline
\end{tabular}

Figure 1 UBE3A mutations in patients from the UF repository. (A) Genomic organisation of UBE3A. UBE3A spans $120 \mathrm{~kb}$ of genomic DNA. The gene is shown to scale. Exons are numbered numerically from 1-16. Transcription (arrow) and translation (ATG) initiation sites are depicted. The primary translation initiation site begins in exon 8 . The location of each mutation is indicated $(A-K)$. (B) Description of mutations. The mutation from each family $(A-K)$ is shown in column 2. Superscripts indicate previously identified mutations. Column 3 describes the predicted protein changes, while column 4 shows the inheritance of the mutation. 
A

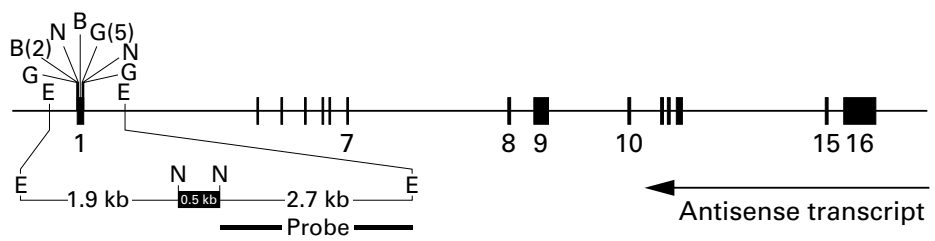

B

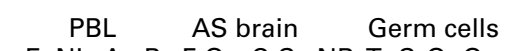

E NLA P F Oc C Sx NB T S OvOv

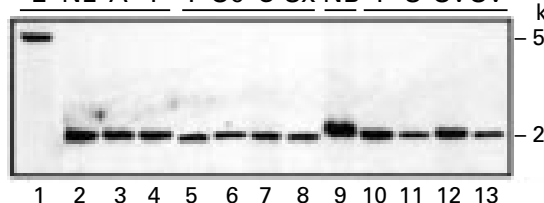

$10 \mathrm{~kb}$

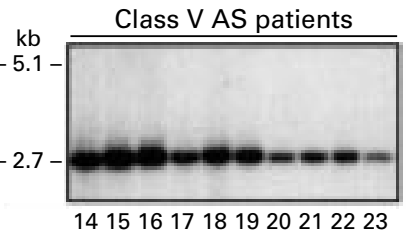

Figure 2 DNA methylation analysis of 5' UBE3A. (A) Genomic structure of UBE3A and the 5' $C p G$ island drawn to scale. Locations of selected restriction enzyme sites are depicted: EcoRI (E), NotI (N), BssHII (B), EagI (G). Localisations of the $2.7 \mathrm{~kb}$ NotI-EcoRI probe as well as the $5.1 \mathrm{~kb}$ region containing the $C p G$ island are indicated. The extent of overlap of the antisense transcript is also shown. If the $C p G$ island is methylated, the $2.7 \mathrm{~kb}$ probe will hybridise to the $5.1 \mathrm{~kb}$ fragment on genomic DNA digested with EcoRI and NotI. If the CpG island is unmethylated, the probe will hybridise to itself, showing a $2.7 \mathrm{~kb}$ band on Southern blots. (B) Southern blot of normal (NL), AS (A), and PWS (P) genomic DNA from peripheral blood leucocytes (PBL); AS brain samples consisting of frontal cortex $(F)$, occipital lobe $(O c)$, cerebellum $(C)$, and coronal section $(S x)$; frontal cortex from normal brain $(N B)$; adult testis $(T)$; sperm $(S)$; and fetal ovary (Ov) digested with EcoRI and NotI. DNA from normal PBL was also digested with EcoRI alone as a control (E). When digested with EcoRI and NotI, the $2.7 \mathrm{~kb}$ probe only hybridised to a $2.7 \mathrm{~kb}$ fragment, indicating that this site was unmethylated. (C) Southern blot analysis of PBL genomic DNA from class $V$ patients digested with EcoRI and NotI shows that this site is unmethylated in all patients.

primers are as follows: methylated primer set (M1F 5'-CGTCGCGGTCGCGAGATT-3' and M1R 5'-ACGCGCCGAATCGACAAAA), unmethylated primer set (U1F 5'-GTG TTGTGGTTGTGAGATTTGTG-3' and U1R 5'-ACAAACACCCA CACTAACAAATA ACT $\left.-3^{\prime}\right)$. The primer sets that amplify the distal $\mathrm{CpG}$ island are as follows: methylated primer set (M2F 5'-GATAGGTAGCGGCGGTTGGC GACGAA-3' and M2R 5'-GCGCCTAAA CTACGACGACCGCCTCA-3', unmethylated primer set (U2F 5'-GAATGTTG GGATTT TGGTGGT-3' and U2R 5'-AAACTACAA CAACCACCTCACTAATCA-3'). PCR products were stained with ethidium bromide and visualised on an Eagle Eye II photodocumentation system (Stratagene).

BESS-T SCAN

We analysed genomic DNA from patients following the procedures outlined in the BESS$\mathrm{T}$ scan mutation detection kit (Epicentre, Madison, WI) using primers (table 1) corresponding to exons $6,10,11,12$, and 16 . Cleaved products were size fractionated on $6 \%$ acrylamide, $6 \mathrm{~mol} / \mathrm{l}$ urea and $30 \%(\mathrm{v} / \mathrm{v})$ formamide sequencing gels according to standard protocols. Putative mutations were verified by sequence analysis.

SEQUENCE ANALYSIS

Abnormal PCR products from BESS-T scan analyses were cloned into TA vectors (Clontech) and sequenced using universal primers on an ABI 377 automated sequencer (ABI, Perkin Elmer). We designed coding region and intronic primers to amplify individual exons of $U B E 3 A$ (table 2). PCR products were purified by the High Pure PCR Purification Kit
(Roche) and sequenced directly using a $1 / 4$ reaction of the Big Dye terminators (ABI, Perkin Elmer). Reactions were purified by either repeated ethanol precipitation or by sepharose columns (Edge Scientific), dried under vacuum, resuspended, and fractionated on either an ABI 377 or ABI 373A automated sequencer. Sequence analysis was performed with the Sequencher program (Gene Codes Corporation).

\section{PRIMERS}

Collectively, primers for BESS-T (table 1) and direct sequence analysis (table 2) were designed to amplify the entire $U B E 3 A$ coding region (exons 6-16). Novel primers were designed using the Primer 3 program from the Whitehead Institute.

\section{STATISTICAL ANALYSES}

Descriptive statistics were calculated as a percentage or by the mean (SD). All outcome variables were modelled as a function of age at evaluation, birth weight, molecular class (I, II, III, IV, and V), gestational age, maternal age, paternal age, race (white, Hispanic, and other), and sex. It should be noted that $93 \%$ of the UF patients and $56 \%$ of the total patients were white. Outcome variables consisted of continuous, binary, and ordinal measures, and were modelled using analysis of covariance (ANCOVA), logistic regression, and ordinal logistic regression, respectively. For binary and ordinal outcome variables with limited sample size, we employed the exact chi-square test. Odds ratios were used to summarise the binary and ordinal outcomes. All tests were two sided and considered significant at alpha $=0.05$. All statistical analyses were performed using SAS 6.12 (SAS Institute, Cary, NC).

\section{Results}

MOLECULAR CLASSES OF ANGELMAN SYNDROME Each patient was assigned a molecular class based upon results from high resolution chromosome, FISH, UBE3A mutation analysis, and DNA dosing, methylation, and polymorphism analyses along 15q11-q13 (table 3). The majority (63) of our classical families were deleted for the entire $4 \mathrm{Mb}$ AS/PWS imprinted domain (class I). In seven cases, AS occurred via paternal UPD of chromosome 15 (class II), and three families had imprinting defects (class III). Intragenic mutations in $U B E 3 A$ occurred in 10 of our classical patients (class IV), while the remaining 10 had no detectable chromosome 15 abnormalities (class V).

\section{MUTATION ANALYSIS}

Initially, a molecular confirmation of AS could not be made in 20/93 families using cytogenetic, DNA methylation, or DNA polymorphism tests. Hybridisation of 5' and 3' UBE3A cDNA probes to Southern blots did not detect genomic rearrangements in these patients (data not shown). However, sequence analysis of the $U B E 3 A$ coding region in these 20 families showed intragenic mutations in 10 families (15 patients). We detected six deletions that resulted in frameshifts, three nonsense mutations, and 
Table 4 Clinical and growth data

\begin{tabular}{|c|c|c|c|c|c|c|c|c|c|c|}
\hline & \multicolumn{2}{|l|}{$p=$} & \multirow{2}{*}{$\begin{array}{l}\text { Class I } \\
U F\end{array}$} & \multicolumn{2}{|c|}{ Class II } & \multicolumn{2}{|c|}{ Class III } & \multicolumn{2}{|c|}{ Class IV } & \multirow{2}{*}{$\begin{array}{l}\text { Class V } \\
U F\end{array}$} \\
\hline & $U F$ & All & & $U F$ & All & $U F$ & All & $U F$ & All & \\
\hline Speech & $4.1 \times 10^{-3}$ & $2.0 \times 10^{-3}$ & $(21)$ & (7) & $(27)$ & $(7)$ & $(20)$ & $(15)$ & $(46)$ & (11) \\
\hline 0 words & & & 71 & $\star$ & 44 & 43 & 40 & 60 & 33 & 82 \\
\hline$<3$ words & & & 29 & 43 & 15 & 14 & 15 & 27 & 26 & 9 \\
\hline $3-10$ words & & & $\star$ & 43 & 33 & 43 & 30 & 13 & 41 & 9 \\
\hline$>10$ words & & & $\star$ & 14 & 8 & $\star$ & 15 & $\star$ & $\star$ & $\star$ \\
\hline Seizure onset $\dagger$ & $6.7 \times 10^{-2}$ & $7.6 \times 10^{-3}$ & (20) & (3) & (14) & (2) & (9) & (12) & $(24)$ & (5) \\
\hline$<1 \mathrm{y}$ & & & 10 & $\star$ & 7 & $\star$ & 33 & 17 & 13 & 40 \\
\hline $1-2 y$ & & & 40 & 33 & 14 & * & 23 & 8 & 4 & 20 \\
\hline $2-3 y$ & & & 25 & $\star$ & 14 & 50 & 11 & 25 & 29 & 40 \\
\hline $3-4 y$ & & & 25 & * & $\star$ & $\star$ & $\star$ & 50 & 29 & $\star$ \\
\hline$>4 \mathrm{y}$ & & & $\star$ & 67 & 65 & 50 & 33 & $\star$ & 25 & $\star$ \\
\hline Seizure severity & $2.0 \times 10^{-3}$ & $1.0 \times 10^{-3}$ & $(21)$ & $(7)$ & $(26)$ & $(7)$ & (18) & (15) & (32) & $(10)$ \\
\hline Severe & & & 29 & $\star$ & 4 & 14 & 6 & 33 & 19 & 10 \\
\hline Moderate & & & 62 & 14 & 8 & $\star$ & 11 & 20 & 22 & 30 \\
\hline Mild & & & 9 & 29 & 23 & 14 & 22 & 33 & 44 & 20 \\
\hline None & & & $\star$ & 57 & 65 & 72 & 61 & 14 & 15 & 40 \\
\hline Height $†$ (centile) & ND & $2.9 \times 10^{-2}$ & $(21)$ & $(7)$ & $(28)$ & $(7)$ & $(17)$ & (15) & $(30)$ & (9) \\
\hline$<5$ & & & 42 & $\star$ & 7 & 30 & 12 & 7 & 10 & $\star$ \\
\hline $5-20$ & & & 5 & $\star$ & 11 & 14 & 12 & 20 & 10 & 56 \\
\hline $21-40$ & & & 14 & 43 & 18 & 14 & 18 & 46 & 27 & 22 \\
\hline $41-60$ & & & 19 & 14 & 14 & 14 & 23 & 13 & 33 & $\star$ \\
\hline $61-80$ & & & 10 & $\star$ & 18 & 14 & 23 & 7 & 17 & 22 \\
\hline $81-95$ & & & 10 & 14 & 21 & 14 & 6 & 7 & 3 & $\star$ \\
\hline$>95$ & & & $\star$ & 29 & 11 & $\star$ & 6 & * & * & * \\
\hline Weight (centile) & $3.4 \times 10^{-3}$ & $3.7 \times 10^{-2}$ & $(21)$ & $(7)$ & $(27)$ & $(7)$ & $(15)$ & (15) & $(28)$ & (9) \\
\hline$<5$ & & & 18 & $\star$ & 4 & $\star$ & $\star$ & $\star$ & $\star$ & 11 \\
\hline $5-20$ & & & 14 & $\star$ & 7 & 29 & 13 & 13 & 7 & 33 \\
\hline $21-40$ & & & 24 & 14 & 4 & $\star$ & $\star$ & $\star$ & $\star$ & 11 \\
\hline $41-60$ & & & 24 & 14 & 15 & 夫 & $\star$ & 27 & 14 & 34 \\
\hline $61-80$ & & & 10 & 14 & 15 & 29 & 13 & 13 & 18 & $\star$ \\
\hline $81-95$ & & & $\star$ & 14 & 22 & $\star$ & 20 & 27 & 18 & * \\
\hline$>95$ & & & 10 & 44 & 33 & 42 & 54 & 20 & 43 & 11 \\
\hline BMI $\left(\mathrm{kg} / \mathrm{m}^{2}\right)$ (centile) & $4.2 \times 10^{-3}$ & $1.7 \times 10^{-2}$ & $(21)$ & $(7)$ & $(17)$ & $(7)$ & $(14)$ & (13) & (13) & (9) \\
\hline$<5$ & & & 10 & $\star$ & $\star$ & $\star$ & $\star$ & 8 & 8 & 11 \\
\hline $5-20$ & & & 10 & * & * & * & * & 8 & 8 & 33 \\
\hline $21-40$ & & & 24 & * & 6 & * & $\star$ & * & $\star$ & $\star$ \\
\hline $41-60$ & & & 18 & 14 & 6 & $\star$ & $\star$ & 8 & 8 & 34 \\
\hline $61-80$ & & & 18 & 14 & 12 & 57 & 29 & 31 & 31 & 11 \\
\hline $81-95$ & & & 10 & 29 & 29 & $\star$ & 7 & 14 & 14 & 11 \\
\hline$>95$ & & & 10 & 43 & 47 & 43 & 64 & 31 & 31 & $\star$ \\
\hline Head circum (centile) & $3.2 \times 10^{-2}$ & $4.2 \times 10^{-2}$ & $(20)$ & $(6)$ & $(27)$ & $(7)$ & (19) & (15) & $(32)$ & (9) \\
\hline$<5$ & & & 60 & $\star$ & 15 & $\star$ & 11 & 53 & 56 & 60 \\
\hline $5-20$ & & & 10 & 33 & 11 & 14 & 5 & $\star$ & $\star$ & 10 \\
\hline $21-40$ & & & 20 & 17 & 30 & 29 & 26 & 27 & 16 & 20 \\
\hline $41-60$ & & & 10 & 33 & 18 & 14 & 21 & 20 & 12 & 10 \\
\hline $61-80$ & & & $\star$ & 17 & 15 & 29 & 21 & $\star$ & $\star$ & $\star$ \\
\hline 81-95 & & & $\star$ & $\star$ & 4 & 14 & 5 & $\star$ & 16 & $\star$ \\
\hline$>95$ & & & $\star$ & * & 7 & $\star$ & 11 & $\star$ & $\star$ & $\star$ \\
\hline
\end{tabular}

Percentage of patients with each trait is indicated, with the sample size in parentheses.

$\mathrm{ND}=$ not determined

$\mathrm{UF}=$ University of Florida data.

All $=$ combined data from UF and published reports.

^No patients in category.

†Statistically significant in combined data set only.

All other parameters are statistically significant in UF and combined data sets.

one missense mutation (fig 1 ). We found a $50 \%$ mutation detection rate with $3 / 4$ familial $(75 \%)$ and $7 / 16$ sporadic cases $(44 \%)$ containing mutations within the coding region of $U B E 3 A$. In our examination of published reports, we found that six of our patients had lesions in $U B E 3 A$ that were identical with previously published mutation sites. Further studies indicated that these sites were not mutation hotspots, but independent reports of mutations in patients $\mathrm{A}$, $\mathrm{B}, \mathrm{C}, \mathrm{D}, \mathrm{E}$, and $\mathrm{G} .{ }^{7-9}$

In addition to disease associated mutations, we also found three novel polymorphisms. A maternally inherited silent transition (A1144G) occurred in exon 9 in one subject. No other mutations were found in this patient. A common polymorphism was detected in a poly $\mathrm{T}$ tract within intron 6 . Sequence analysis of 67 subjects showed that $17 \%$ of the chromosomes $(p=0.83$, $\mathrm{q}=0.17$ ) contained a $1 \mathrm{bp}$ thymidine insertion at nucleotide position -47 , relative to exon 7 . One AS-like patient had a paternally inherited $14 \mathrm{bp}$ deletion of the 3' UTR. No disease associated mutation was found in this person. In addition, BESS-T scan detected one subject who was homozygous for a previously identified expressed polymorphism in exon $6 .^{34}$

\section{DNA METHYLATION OF 5' UBE3A}

Although we identified disease causing mutations in $50 \%$ of our patients who had normal DNA methylation along 15q11-q13, the aetiology of AS in the remainder of our classical Angelman syndrome patients was unknown. We postulated that disruption of the normal $U B E 3 A$ DNA methylation pattern in class $\mathrm{V}$ patients could be causative of AS in these patients.

Using rare cutting restriction enzymes, we isolated a $2.7 \mathrm{~kb} N o t \mathrm{I}-E c o \mathrm{RI}$ fragment from the $\mathrm{CpG}$ island at 5' $U B E 3 A$ to test for parent of 


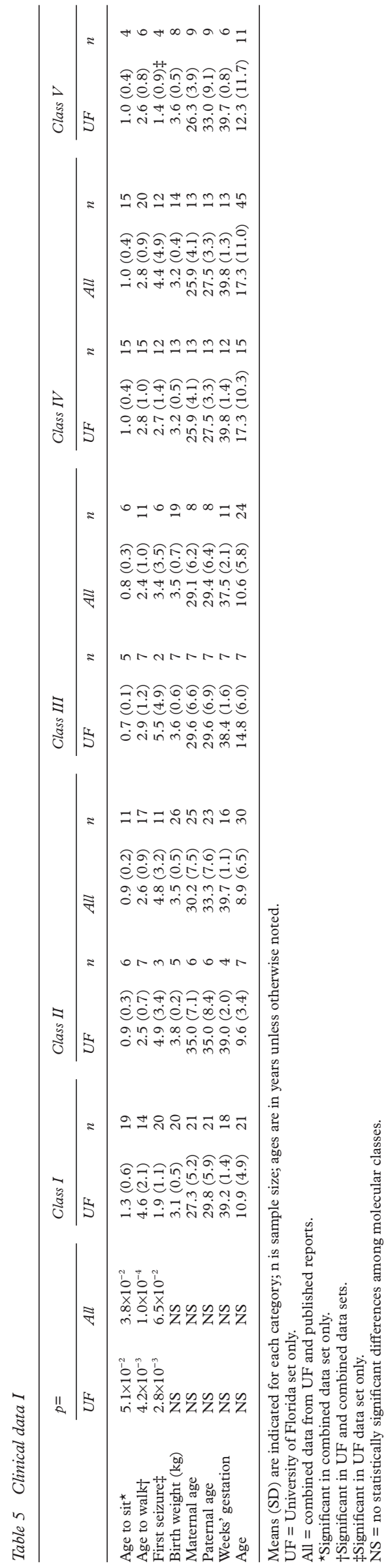

origin DNA methylation imprints in DNA from peripheral blood leucocytes (PBL), AS brain, normal brain, and germ cells from both sexes. The $2.7 \mathrm{~kb}$ genomic probe detected a 5.1 $\mathrm{kb}$ fragment when the DNA was digested with EcoRI alone. However, when DNA was digested with both EcoRI and NotI, the probe only hybridised to a $2.7 \mathrm{~kb}$ fragment (fig $2 \mathrm{~B}$ ). In addition, we used methylation specific PCR (MSP) to assess the DNA methylation status of $U B E 3 A$ in DNA from peripheral blood leucocytes and skin fibroblast cell lines. We analysed two regions of the $\mathrm{CpG}$ island. In both regions, only the unmethylated allele amplified, indicating that the regions covered by our primers are unmethylated (data not shown). Using these two independent methods, we found no evidence for methylation within these sites. We next examined PBL DNA from class V patients. The $2.7 \mathrm{~kb}$ probe only detected the unmethylated fragment, indicating that de novo methylation at this site did not occur in these subjects (fig $2 \mathrm{C}$ ).

\section{GENOTYPE-PHENOTYPE CORRELATIONS}

We analysed phenotypic data on 61 patients from the University of Florida AS repository. We included all of our patients from classes II-V and randomly chose 20 class I (deletion) patients for clinical comparisons. Also included in our statistical models were 77 additional patients (classes II, III, and IV) gathered from published reports. ${ }^{10}{ }^{11} 18-22$ 35-56

We compared the results of statistical models established between our patients and the combined data set (tables 4, 5, and 6). Statistical analysis of body mass index (BMI) showed that patients from classes II, III, and IV were taller and heavier than the deletion and class $\mathrm{V}$ patients (fig 3A, table 4), for both UF patients $(p=0.0042)$ and the combined data set $(\mathrm{p}=0.0167)$. The data also showed that less than $15 \%$ of subjects from classes II and III had microcephaly, whereas more than $55 \%$ of patients from the other three classes had a head circumference below the 3rd centile (fig 3B, table $4, \mathrm{p}=0.0415$ ).

Although all AS patients showed delayed development of gross motor skills, the deletion patients as a group were more severely affected. One of the most striking observations was that $50 \%$ of deletion patients were non-ambulatory at 5 years, while over $95 \%$ of patients from the other classes had the ability to walk unassisted by 5 years (table $6, p=1.1 \times 10^{-5}$ ). The mean age to walk also differed significantly among the classes. Patients in class I walked at a mean age of 4.6 (SD 2.1) years $(\mathrm{p}=0.0001)$, while patients in classes II-V walked much earlier, with mean ages varying from 2.4 (SD 0.9) (class III) to 2.8 (SD 0.9) years of age (class IV, fig 3C, table 5).

Onset of seizures also depended upon molecular class (fig 3D, table 5). Seizures began very early in class I and V patients (1.9 (SD 1.1) and 1.4 (SD 0.9) years, respectively) compared to classes II, III, and IV (4.9 (SD 3.4, 5.5 (SD 5.0), and 2.7 (SD 1.4) years, respectively; $p=0.0028)$. In the $U F$ patient population, significant seizures (that is, grand mal seizures requiring the use of at least one 
Table 6 Clinical data II

\begin{tabular}{|c|c|c|c|c|c|c|c|c|c|c|c|c|c|c|c|c|c|c|}
\hline & \multicolumn{2}{|l|}{$p=$} & \multicolumn{2}{|c|}{ Class I } & \multicolumn{4}{|c|}{ Class II } & \multicolumn{4}{|c|}{ Class III } & \multicolumn{4}{|c|}{ Class IV } & \multicolumn{2}{|c|}{ Class V } \\
\hline & $U F$ & All & $U F$ & (n) & $U F$ & (n) & All & (n) & $U F$ & (n) & All & (n) & $U F$ & (n) & All & (n) & $U F$ & $(n)$ \\
\hline Walk by $5 y^{\star}$ & $2.9 \times 10^{-3}$ & $1.1 \times 10^{-5}$ & 50 & $(20)$ & 100 & (7) & 96 & (25) & 86 & (7) & 94 & (18) & 93 & (15) & 97 & (35) & 100 & $(7)$ \\
\hline $\begin{array}{l}\text { Feeding problems } \\
\text { (NS) } \\
\text { Simple }\end{array}$ & $0.6 \times 10^{-1}$ & $1.2 \times 10^{-1}$ & 70 & $(20)$ & 80 & (5) & 75 & (12) & 100 & (5) & 83 & (18) & 80 & (10) & 46 & (24) & 63 & $(8)$ \\
\hline $\begin{array}{l}\text { commands } \\
\text { Seizures }\end{array}$ & $\begin{array}{l}3.1 \times 10^{-3} \\
6.3 \times 10^{-4}\end{array}$ & $\begin{array}{l}1.2 \times 10^{-3} \\
6.8 \times 10^{-4}\end{array}$ & $\begin{array}{r}53 \\
100\end{array}$ & $\begin{array}{l}(17) \\
(21)\end{array}$ & $\begin{array}{r}100 \\
43\end{array}$ & $\begin{array}{l}(4) \\
(7)\end{array}$ & $\begin{array}{l}91 \\
45\end{array}$ & $\begin{array}{l}(11) \\
(31)\end{array}$ & $\begin{array}{r}100 \\
29\end{array}$ & $\begin{array}{l}(7) \\
(7)\end{array}$ & $\begin{array}{r}100 \\
59\end{array}$ & $\begin{array}{l}(13) \\
(27)\end{array}$ & $\begin{array}{r}100 \\
53\end{array}$ & $\begin{array}{l}(13) \\
(15)\end{array}$ & $\begin{array}{r}100 \\
73\end{array}$ & $\begin{array}{l}(13) \\
(48)\end{array}$ & $\begin{array}{r}100 \\
60\end{array}$ & $\begin{array}{l}(5) \\
(10)\end{array}$ \\
\hline $\begin{array}{l}\text { Significant } \\
\quad \text { seizures } \\
\text { Hypopigmented }^{\star}\end{array}$ & $\begin{array}{l}1.0 \times 10^{-4} \\
3.3 \times 10^{-7}\end{array}$ & $\begin{array}{l}8.3 \times 10^{-8} \\
2.8 \times 10^{-8}\end{array}$ & $\begin{array}{l}90 \\
90\end{array}$ & $\begin{array}{l}(21) \\
(21)\end{array}$ & $\begin{array}{l}14 \\
17\end{array}$ & $\begin{array}{l}(7) \\
(6)\end{array}$ & $\begin{array}{l}12 \\
20\end{array}$ & $\begin{array}{l}(26) \\
(20)\end{array}$ & $\begin{array}{r}14 \\
0\end{array}$ & $\begin{array}{l}(7) \\
(7)\end{array}$ & $\begin{array}{l}17 \\
14\end{array}$ & $\begin{array}{l}(18) \\
(22)\end{array}$ & $\begin{array}{l}53 \\
15\end{array}$ & $\begin{array}{l}(15) \\
(13)\end{array}$ & $\begin{array}{l}41 \\
23\end{array}$ & $\begin{array}{l}(41) \\
(43)\end{array}$ & $\begin{array}{l}40 \\
44\end{array}$ & $\begin{array}{l}(10) \\
(9)\end{array}$ \\
\hline
\end{tabular}

Percentages of patients with each phenotype are indicated under category, with the sample size shown in parentheses.

UF $=$ University of Florida set only.

All = combined data from UF and published reports

*Significant in both data sets.

NS $=$ not significant.

anticonvulsant) occurred in $19 / 21$ deletion patients, but only in 1/7 UPD, $1 / 7 \mathrm{ID}, 8 / 15$ UBE3A mutation, and $4 / 10$ class $\mathrm{V}$ patients $\left(\mathrm{p}=9.96 \times 10^{-5}\right)$. Similar findings were observed in the combined data set (table $6, p=8.26 \times$ $\left.10^{-8}\right)$. In addition, $90 \%$ of class I patients were hypopigmented compared to family members $\left(\right.$ table $\left.6, \mathrm{p}=3.33 \times 10^{-8}\right)$. However, less than $25 \%$ of classes II-IV and $44 \%$ of patients in class $\mathrm{V}$ showed evidence of hypopigmentation.

\section{Discussion}

MOLECULAR BASIS OF AS IN CLASSES IV AND V Molecular analyses showed that 20 of the 104 classical patients with AS (93 families) we studied had normal DNA methylation at several imprinted 15q11-q13 loci, excluding large deletions, UPD, or imprinting defects from the aetiologies of AS in these subjects. We found mutations in $50 \%$ of these patients, with

A

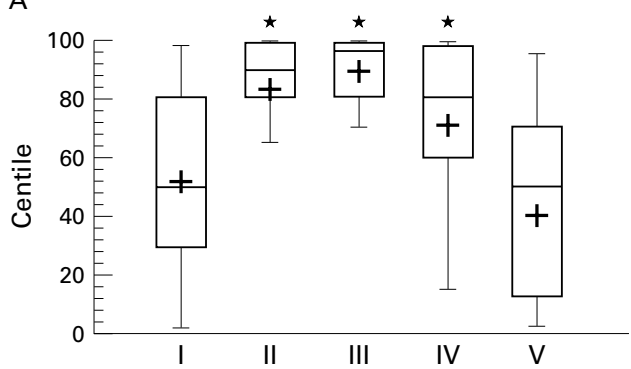

C

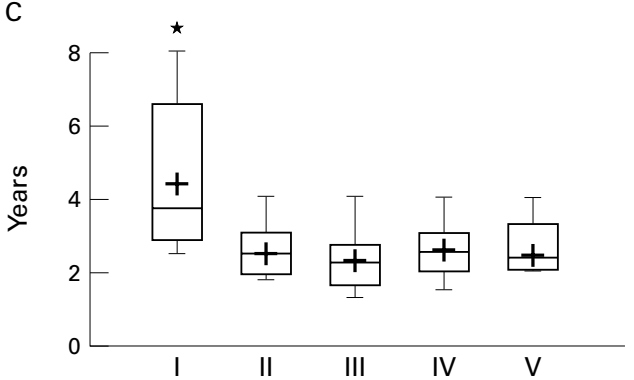

$44 \%(7 / 16)$ of our sporadic and $75 \%(3 / 4)$ of our familial cases having mutations within $U B E 3 A$. Recent mutation analyses by other laboratories showed a lower UBE3A mutation frequency $(5-38 \%)$ in their sporadic patients. $^{8-1257}$

Including our patients, $U B E 3 A$ mutations have been identified in 51 AS families. ${ }^{8} 125457$ Forty-five are unique mutations (fig 4), with no more than three unrelated subjects sharing a common error. Most defects are nonsense mutations that are predicted to result in premature termination during translation, and therefore may not represent true null mutations. However, the last six amino acids of $U B E 3 A$ are crucial for normal protein function in the presence of human papillomavirus, ${ }^{58}$ and it is possible that these mutations produce unstable message owing to nonsense mediated decay. ${ }^{59}{ }^{60}$ Although defects have been found in

B

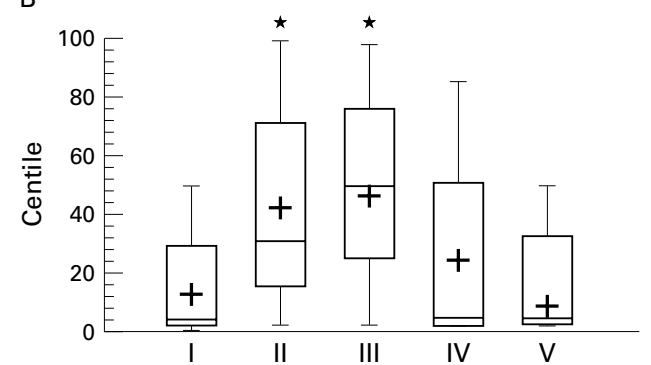

D

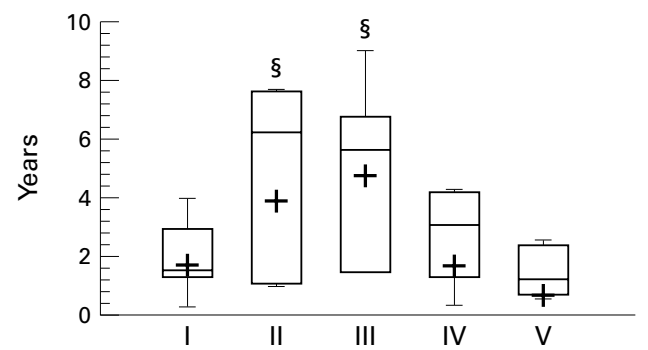

Figure 3 Mean BMI, HC, age to walk, and onset of seizures. Boxes show the extent of 25-75\% of the patients, while bars (T) depict the range. The medians $(-)$ and means $(+)$ for each class are shown. Phenotypes that are statistically significant in the UF and combined data sets ( $\left.{ }^{*}\right)$ or in the UF data only (§) are indicated. Molecular class (I-V) is shown at the bottom of each graph. The centiles $(A$ and $B)$ and age in years $(C$ and $D)$ are shown on the left. $(A)$ Body mass index centiles. Statistically, patients in classes II, III, and IV have higher BMI percentages than patients in classes I and V. (B) Head circumference centiles. Patients in classes II and III are statistically different from patients in class I, but not from patients in classes $I V$ and $V$. There are no statistically significant differences between classes $I, I V$, and $V$. (C) Mean age to walk. Statistically significant differences are observed in patients in class I compared with the other four classes. (D) Mean age at onset of seizures. In the UF data set, seizures, when they occur, start much later in classes II and III than the other classes. 


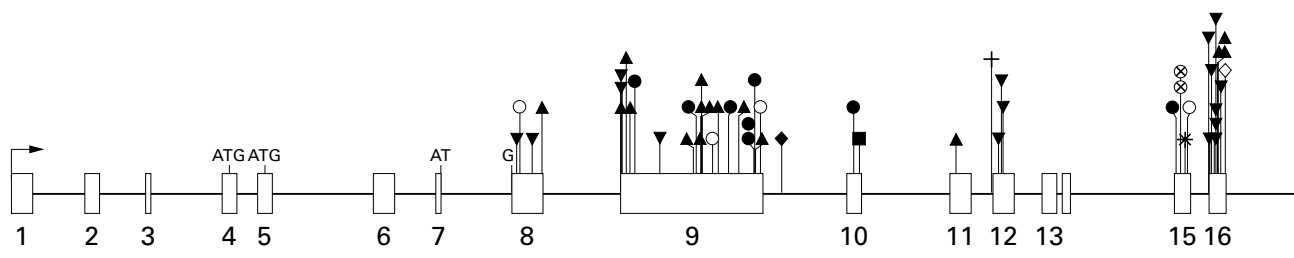

$\boldsymbol{\nabla}$ Out of frame insertion

A Out of frame deletion

$\checkmark$ Splicing mutation

Out of frame deletion/insertion

- Nonsense mutation
Missense mutation

* In frame insertion

$\otimes$ In frame deletion

$\diamond$ In frame deletion - elongated protein

+ Putative splicing mutation

Figure 4 Summary of all published mutations in UBE3A. The gene is shown to scale. Exons are numbered numerically from 1-16. Transcription (arrow) and translation ( $A T G$ ) start sites are noted. The primary translation initiation site begins in exon 8. The location of each mutation is indicated by a symbol. Filled symbols indicate protein truncating mutations. Symbols are stacked at positions where two unrelated subjects share a common mutation. There are 51 total mutations in unrelated subjects. Forty-five mutations are unique. Familial mutations are counted once. Most mutations (38/45) are protein truncating and cluster in exons 9 and 16.

virtually all protein coding exons, most cluster in exons 9 and 16 (fig 4). Exon 16 is within the HECT domain, a region of high conservation between different $\mathrm{E} 3$ protein ligases.

Although our study has shown the highest $U B E 3 A$ mutation frequency found to date in sporadic cases, our results indicate that approximately $11 \%$ of patients with AS have an unknown aetiology. Alternative explanations must account for the molecular basis of AS in this group. Five possible explanations follow. (1) Many $U B E 3 A$ mutations occur in noncoding regions; (2) $U B E 3 A$ can be inactivated by other mechanisms; (3) other genes, some of which may reside in the ubiquitin pathway (genome wide), can also cause AS; (4) AS associated mutations can occur in other 15q11-q13 genes; (5) these patients do not have AS, but instead have disorders that mimic AS. ${ }^{61}$ However, our rigorous clinical criteria and extensive clinical expertise with AS suggest that the last explanation is unlikely.

Although the relative lack of $U B E 3 A$ mutations in patients with normal DNA methylation could be accounted for if various mutations occurred outside the $U B E 3 A$ coding region, we did not detect genomic rearrangements in any of our 20 families, and only one genomic rearrangement has been identified to date. ${ }^{53}$ Furthermore, no mutations have been reported in the promoter region or 3' UTR of $U B E 3 A$.

We postulated that disruption of the normal DNA methylation pattern at 5' UBE3A could inactivate the gene. With the exception of only a few genes, the promoter regions of most imprinted genes show differential methylation based on the parental origin of the chromosome. ${ }^{62}{ }^{63}$ In the AS/PWS domain, several paternal only expressed genes display parent of origin DNA methylation imprints, with the promoters of the active allele being hypomethylated compared to the inactive allele. ${ }^{24-26} 64-66$ Since DNA methylation of promoter regions is closely associated with transcriptional repression, ${ }^{68}$ we hypothesised that methylation of the maternally derived $5^{\prime} \mathrm{CpG}$ island of $U B E 3 A$ could repress imprinted expression in class $\mathrm{V}$ patients. In addition, recent experiments suggested that in somatic cell hybrid cell lines, which are derived from skin fibroblasts, $U B E 3 A$ was methylated on the maternal allele ${ }^{67}$ However, in contrast to Meguro et al, ${ }^{67}$ we found that both parental alleles of $U B E 3 A$ were completely unmethylated in PBL, skin fibroblasts, germ cells, and brain, which has been shown to demonstrate imprinted expression of $U B E 3 A .{ }^{14}$ In addition, class $\mathrm{V}$ patients were completely unmethylated at $5^{\prime} U B E 3 A$ in PBL DNA, indicating that they probably do not inactivate $U B E 3 A$ by inappropriate methylation. To eliminate this possibility fully, brain DNA from class $V$ patients should be examined.

Our data suggest that disruption of $U B E 3 A$ may not be the only cause of AS and other factors may also be involved. The most obvious candidates are other genes in the ubiquitin pathway. Any protein that regulates or interacts with UBE3A in this cascade and all proteins that UBE3A targets for degradation are candidates for patients grouped in class V. So far, four proteins have been identified as substrates for UBE3A mediated degradation: p53, HHR23A, the Src family kinase Blk, and UBE3A itself. ${ }^{69-74}$

Alternatively, other 15q11-q13 genes may play important roles in the aetiology of class $\mathrm{V}$ patients. The $U B E 3 A$ antisense transcript is one candidate, as preliminary data suggest that the paternally expressed antisense transcript is restricted to the brain. ${ }^{75}$ It is possible that expression of the antisense transcript from the paternal chromosome specifically inactivates the paternal $U B E 3 A$ allele in cis. According to this model, biallelic activation of the antisense transcript would result in repression of both $U B E 3 A$ alleles. It would be important to know if class $\mathrm{V}$ patients show biallelic expression of the $U B E 3 A$ antisense transcript in the regions of the brain that shows imprinted expression of 
$U B E 3 A$. Another excellent candidate gene is the newly identified imprinted gene ATP10C. This gene is located approximately $200 \mathrm{~kb}$ distal to $U B E 3 A$ and is preferentially expressed from the maternal allele in human brain. ${ }^{76}{ }^{77} \mathrm{It}$ would be interesting to determine if some of our class $\mathrm{V}$ patients have lesions within this new candidate gene.

GENOTYPE-PHENOTYPE CORRELATIONS

The second major goal of this study was to establish phenotypic profiles for each molecular class. Genotype-phenotype analyses of our patients indicated that all five classes had the four cardinal features of AS (that is, severe developmental delay, profound speech impairment, a movement and balance disorder, and characteristic behaviour). Statistical models showed that the five classes could be separated into four phenotypic groups: class I, classes II and III, class IV, and class V. The statistically significant clinical distinctions between the classes include 16 of 22 parameters $(p<0.05)$, and were most striking for pigmentation, growth parameters, achievement of developmental milestones, and severity, frequency, and age of onset of seizures.

We found that the class I (deletion) patients as a group have the most classical and severe phenotype. They achieve developmental milestones later and to a lesser degree than the other classes. Statistical models show that deletion patients learn to sit and walk later than the other classes and are less likely to be able to follow simple commands. Class I patients have the highest incidence of severe seizures (90\%) and hypopigmentation (90\%) of all five classes. In addition, deletion patients typically have a complete absence of speech, a normal BMI distribution, and severe microcephaly.

In contrast, UPD and ID patients (whom we found as a group to have indistinguishable phenotypes) are much less severely affected. They have a low incidence of hypopigmentation, microcephaly, and severe seizures. In addition, almost half of UPD and ID patients have more than three words in their vocabulary. Patients in classes II and III are larger and heavier than class I patients. Analysis of body weight by BMI showed that more than $70 \%$ of these patients are above the 80th centile for their age group. Our data from these two classes correlate well with the combined data of others who also found fewer incidences of hypopigmentation, microcephaly, or seizures in UPD and ID patients. ${ }^{17-214145}$

$U B E 3 A$ mutation patients fall somewhere in the middle. They are statistically similar to deletion patients with respect to seizures, absence of speech, and microcephaly. Moncla et $a l^{2}$ examined class IV patients individually for head circumference and seizures, and similarly concluded that $U B E 3 A$ mutation patients had high incidences of seizures and microcephaly. Statistically, the class IV patients that we examined are similar to UPD and ID patients in the development of motor skills, ability to follow simple commands, pigmentation, and development of obesity. Class IV patients have a high incidence of early onset obesity. Perhaps UBE3A functions in the same pathway as the newly discovered $A T P 10 C$ gene, whereby lesions in $U B E 3 A$ also alter expression of $A T P 10 C$. In addition, UBE3A mutation patients differ from UPD and ID patients in that they were more likely to have a history of moderate to severe seizures and microcephaly. Although milder than deletion patients, class IV cases have a more typical phenotype than class II or III patients, indicating that lesions in $U B E 3 A$ have pleiotropic consequences.

Class V patients are very interesting. Although these patients have no detectable chromosome 15 abnormalities, statistically they are most similar to the deletion patients. Class V patients have normal height, weight, and BMI distributions, similar to those observed in class I patients. They also frequently present with a complete absence of speech, early onset of seizures, hypopigmentation, and microcephaly. The observation of hypopigmentation in these patients is unexpected. One possible explanation could be that the hypopigmented subjects are haploinsufficient for the $P$ gene or for another pigmentation gene located elsewhere in the genome. However, class V patients differ from deletion patients in two important characteristics. They walk about two years earlier than deletion patients and they are less likely to have seizures compared to patients in class I.

In addition, class $\mathrm{V}$ patients tend to have a more severe phenotype than that observed in classes II, III, and IV. It is possible that disruption of more than one gene is causative of the class $\mathrm{V}$ phenotype in these patients. Perhaps these patients have mutations in a gene or "controlling region" in $15 \mathrm{q} 11-\mathrm{q} 13$ that affects additional loci within the domain, such as $A T P 10 C$, giving rise to the more severe phenotype. Alternatively, these patients may have defects upstream of $U B E 3 A$ that alter additional genes within the ubiquitin pathway. However, some class $\mathrm{V}$ patients could suffer from a loss of function mutation in a UBE3A target protein. This could lead to a more severe phenotype than that observed in $U B E 3 A$ mutation patients, who presumably experience an upregulation of a critical UBE3A target protein. In addition, two recent papers have shown a link between "AS-like" subjects and $M E C P 2 .{ }^{78}{ }^{79}$ Although at least one of our "ASlike" patients was later diagnosed with Rett syndrome, it remains to be seen if any of our class $\mathrm{V}$ patients have mutations in $M E C P 2$, the gene responsible for Rett syndrome.

Our data indicate that class I patients comprise a contiguous gene disorder, with haploinsufficiency of additional non-imprinted genes exacerbating the lack of the maternally expressed $U B E 3 A$ gene. For example, hypopigmentation has been linked to haploinsufficiency of the $P$ gene in PWS deletion patients, ${ }^{80}$ and the inheritance of a single copy of the $G A B R B 3$ gene has been implicated in seizure susceptibility. ${ }^{81}$ Our data clearly show that patients in classes II and III have the least severe and most atypical phenotype, suggesting that a "double dose" of the paternal only 
expressed genes may ameliorate the AS phenotype in these patients. In addition, the finding that class II and III patients are larger and have better motor skills than the other patients with AS may have implications for the "parental conflict" hypothesis, which states that paternally expressed genes are involved in embryonic or postnatal growth. ${ }^{82}$ For our findings to support this hypothesis, it will be important to establish if the increased growth and obesity observed in UPD and ID patients occurs while the offspring is still capable of using maternal resources (for example, breast feeding).

Another important finding is that almost half of the $U B E 3 A$ mutation patients and $70-75 \%$ of the UPD/ID patients have extremely high $\mathrm{BMI}$ ratios (above the 80th centile). Obesity is also observed in several mouse models of AS. Mice that have paternal UPD for the AS orthologous region, ${ }^{83}$ a $4 \mathrm{Mb}$ maternally derived deletion of the AS/PWS region ${ }^{84}$ (Nicholls, unpublished data), or a smaller maternally derived deletion in this region, ${ }^{85} 86$ have adult onset obesity. Genetic studies in the mouse have mapped a maternally expressed "fat" gene ( $p f a t p)$ very close to the UBE3A gene. ${ }^{85}$ The human orthologue, ATP10C, shows imprinted expression in human brain and maps very close to UBE3A..$^{76} 77$ An integrated hypothesis would suggest that $U B E 3 A$ and/or another closely linked gene (that is, ATP10C) play a role in metabolism and/or feeding behaviour. The relative lack of obesity in class I patients could be caused by the severe underlying motor defects associated with deletion patients.

This comprehensive and extensive study of genotype-phenotype correlations provides additional delineation and enhances our understanding of the distinct clinical subgroups of AS. Our data indicate that patients with a high body mass index and a history of significant seizures would be good candidates for $U B E 3 A$ mutation analysis. It is clear that although mutations in $U B E 3 A$ are sufficient to cause the four cardinal features of Angelman syndrome, as well as recurrent seizures and microcephaly, other $15 \mathrm{q} 11-\mathrm{q} 13$ genes must contribute to the development of motor skills, severity of seizures, cognition, growth, and obesity found in the other classes of AS. Elucidating the role of these other 15q11-q13 genes will give us important insights into mammalian development and into an improved understanding of contiguous gene deletion disorders. Delineating all the UBE3A target proteins could promote the design of rational therapies for AS. Furthermore, discovery of the molecular mechanism(s) involved in the pathogenesis of class $\mathrm{V}$ patients will be crucial to our full understanding of Angelman syndrome and the molecular complexity governing phenotypic expression of imprinted genes.

Electronic database information. Accession number and URL for data in this article are as follows. Online Mendelian Inheritance in Man (OMIM), http://www.ncbi.nlm.nih.gov/Omim (for AS in Man (OMIM), http://www.ncbi.nlm.nih.gov/Omim (for AS bin/primer/primer3_www.cgi. GeneClinics, http://www. geneclinics.org/profiles/angelman
We would first like to acknowledge the support of our AS families who have participated in our research over the last decade. We also thank Peter Howley, who provided us with valuable information about the $U B E 3 A$ gene, and Joseph Wagstaff, who kindly furnished us details of his $U B E 3 A$ mutation analysis. We appreciate the excellent technical assistance of Amy MacNeill and Brian Sage, and thank Chris Glenn, Fatih Boyar, and Elaine Whidden for early contributions. This work was supported in part by NIH grants 2R01HD31491 (RDN and DJD), R01HD36417 (DJD), K24HD1361 (DJD), and the University of Florida General Clinical Research Center grant RR00082, as well as funding from the Hayward Foundation and the R C Philips Unit.

1 Clayton-Smith J, Driscoll DJ, Waters MF, Webb T, Andrews T, Pembrey ME, Malcolm S, Nicholls RD. Differences in methylation patterns within the D15S9 region of chromosome 15q11-q13 in first cousins with Angelman and Prader-Willi syndromes. Am F Med Genet 1993;47:683-6.

2 Angelman H. "Puppet" children: a report on three cases. Dev Med Child Neurol 1965;7:681-8.

3 Williams CA, Angelman H, Clayton-Smith J, Driscoll DJ, Hendrickson JE, Knoll JH, Magenis RE, Schinzel A, Wagstaff J, Whidden EM, Zori RT. Angelman syndrome: consensus for diagnostic criteria. Angelman Syndrome Foundation. Am ₹Med Genet 1995;56:237-8.

4 Williams CA, Lossie AC, Driscoll DJ. Angelman syndrome. GeneClinics 2000.

5 Glenn CC, Driscoll DJ, Yang TP, Nicholls RD. Genomic imprinting: potential function and mechanisms revealed by the Prader-Willi and Angelman syndromes. Mol Hum the Prader-Willi and

6 Kishino T, Lalande M, Wagstaff J. UBE3A/E6-AP mutations cause Angelman syndrome. Nat Genet 1997;15:70-3.

7 Matsuura T, Sutcliffe JS, Fang P, Galjaard RJ, Jiang YH, Benton CS, Rommens JM, Beaudet AL. De novo truncating mutations in E6-AP ubiquitin-protein ligase gene $(U B E 3 A)$ in Angelman syndrome. Nat Genet 1997;15:74-7.
Malzac P, Webber H, Moncla A, Graham JM, Kukolich M, Williams C, Pagon RA, Ramsdell LA, Kishino T, Wagstaff J. Mutation analysis of UBE3A in Angelman syndrome patients. Am f Hum Genet 1998;62:1353-60.

9 Fang P, Lev-Lehman E, Tsai TF, Matsuura T, Benton CS, Sutcliffe JS, Christian SL, Kubota T, Halley DJ, MeijersHeijboer H, Langlois S, Graham JM Jr, Beuten J, Willems PJ, Ledbetter DH, Beaudet AL. The spectrum of mutations in UBE3A causing Angelman syndrome. Hum Mol Genet 1999;8:129-35.

10 Moncla A, Malzac P, Livet MO, Voelckel MA, Mancini J, Delaroziere JC, Philip N, Mattei JF. Angelman syndrome resulting from UBE3A mutations in 14 patients from eight families: clinical manifestations and genetic counselling. $f$ Med Genet 1999;36:554-60

11 Russo S, Cogliati F, Viri M, Cavalleri F, Selicorni A, Turolla L, Belli S, Romeo A, Larizza L. Novel mutations of ubiquitin protein ligase 3A gene in Italian patients with Angelman syndrome. Hum Mutat 2000;15:387.

12 Baumer A, Balmer D, Schinzel A. Screening for UBE3A gene mutations in a group of Angelman syndrome patients selected according to non-stringent clinical criteria. Hum Genet 1999;105:598-602.

13 Nakao M, Sutcliffe JS, Durtschi B, Mutirangura A, Ledbetter DH, Beaudet AL. Imprinting analysis of three genes in the Prader-Willi/Angelman region: SNRPN, E6-associated protein, and PAR-2 (D15S225E). Hum Mol Genet 1994;3: protein,

14 Rougeulle C, Glatt $\mathrm{H}$, Lalande $M$. The Angelman syndrome candidate gene, $U B E 3 A / E 6-A P$, is imprinted in brain. Nat candidate gene, UBE3A/

15 Saitoh S, Harada N, Jinno Y, Hashimoto K, Imaizumi K, Kuroki Y, Fukushima Y, Sugimoto T, Renedo M, Wagstaff J. Molecular and clinical study of 61 Angelman syndrome patients. Am ₹ Med Genet 1994;52:158-63.

16 Smith A, Wiles C, Haan E, McGill J, Wallace G, Dixon J, Selby R, Colley A, Marks R, Trent RJ. Clinical features in 27 patients with Angelman syndrome resulting from DNA deletion. F Med Genet 1996;33:107-12.

17 Burger J, Kunze J, Sperling K, Reis A. Phenotypic differences in Angelman syndrome patients: imprinting mutations show less frequently microcephaly and hypopig-

18 Gillessen-Kaesbach G, Demuth S, Thiele H, Theile U, Lich C, Horsthemke B. A previously unrecognised phenotype C, Horsthemke B. A previously unrecognised phenotype speak in patients with Angelman syndrome caused by an imprinting defect. Eur f Hum Genet 1999;7:638-44.

19 Saitoh S, Wada T, Kuno T, Kim KC, Ohashi H, Hashimoto K, Niikawa N. Clinical characteristics of Angelman syndrome patients with a non-IC-deleted imprinting mutation. Clin Genet 1999;55:277-8.

20 Fridman C, Varela MC, Kok F, Diament A, Koiffmann CP. Paternal UPD15: further genetic and clinical studies in four Angelman syndrome patients. Am $\mathcal{F}$ Med Genet 2000; 92:322-7.

21 Smith A, Marks R, Haan E, Dixon J, Trent RJ. Clinical features in four patients with Angelman syndrome resulting from paternal uniparental disomy. $\mathcal{F}$ Med Genet 1997;34: 426-9.

22 Moncla A, Malzac P, Voelckel MA, Auquier P, Girardot L, Mattei MG, Philip N, Mattei JF, Lalande M, Livet MO. Phenotype-genotype correlation in 20 deletion and 20 non-deletion Angelman syndrome patients. Eur $\mathcal{f}$ Hum Gonet 1999;7:131-9. 
23 Dittrich B, Buiting K, Gross S, Horsthemke B. Characterization of a methylation imprint in the Prader-Will syndrome chromosome region. Hum Mol Genet 1993;2: 1995-9.

24 Driscoll DJ, Waters MF, Williams CA, Zori RT, Glenn CC, Avidano KM, Nicholls RD. A DNA methylation imprint, determined by the sex of the parent, distinguishes the Angelman and Prader-Willi syndromes. Genomics 1992;13 917-24.

25 Sutcliffe JS, Nakao M, Christian S, Orstavik KH, Tommerup N, Ledbetter DH, Beaudet AL. Deletions of a differentially methylated CpG island at the SNRPN gene define a putative imprinting control region. Nat Genet 1994;8:52-8.

26 Glenn CC, Saitoh S, Jong MT, Filbrandt MM, Surti U, Driscoll DJ, Nicholls RD. Gene structure, DNA methylation, and imprinted expression of the human SNRPN gene. Am F Hum Genet 1996;58:335-46.

27 Kubota T, Sutcliffe J, Aradhya S, Gillessen-Kaesbach G, Christian S, Horsthemke B, Beaudet A, Ledbetter D. Validation studies of SNRPN methylation as a diagnostic tes for Prader-Willi syndrome. Am $\mathcal{F}$ Med Genet 1996;66: $77-80$.

28 Gray TA, Saitoh S, Nicholls RD. An imprinted, mammalian bicistronic transcript encodes two independent proteins. Proc Natl Acad Sci USA 1999;96:5616-21.

29 Glenn CC, Nicholls RD, Saitoh S, Niikawa N, Robinson WP, Schinzel A, Horsthemke B, Driscoll DJ. Modification of 15 q11-q13 methylation imprints in unique Angelman of 15q11-q13 methylation imprints in unique Angelman

30 Miturangura A, Greenberg F, Butler MG, Malcolm S, Nicholls RD, Chakravarti A, Ledbetter DH. Multiplex PCR of three dinucleotide repeats in the Prader-Willi/ Angelman critical region (15q11-q13): molecular diagnosis and mechanism of uniparental disomy. Hum Mol Gene 1993;2:143-51.

31 Christian SL, Bhatt NK, Martin SA, Sutcliffe JS, Kubota T, Huang B, Mutirangura A, Chinault AC, Beaudet AL, Ledbetter DH. Integrated YAC contig map of the Prader-Willi/ Angelman region on chromosome $15 \mathrm{q} 11-\mathrm{q} 13$ with average STS spacing of $35 \mathrm{~kb}$. Genome Res 1998;8:146-57.

32 Lossie AC, Driscoll DJ. Transmission of Angelman syndrome by an affected mother. Genet Med 1999;1:262-6.

33 Kubota T, Das S, Christian SL, Baylin SB, Herman JG, Ledbetter DH. Methylation-specific PCR simplifies imprinting analysis. Nat Genet 1997;16:16-17.

$34 \mathrm{Vu} \mathrm{TH}$, Hoffman AR. Imprinting of the Angelman syndrome gene, $U B E 3 A$, is restricted to brain. Nat Genet 1997; 17:12-13.

35 Malcolm S, Clayton-Smith J, Nichols M, Robb S, Webb T, Armour JAL, Jeffreys AJ, Pembrey ME. Uniparental paternal disomy in Angelman's syndrome. Lancet 1991;337:6947 .

36 Smeets DF, Hamel BC, Nelen MR, Smeets HJ, Bollen JH, Smits AP, Ropers HH, van Oost BA. Prader-Willi syndrome and Angelman syndrome in cousins from a family with a translocation between
Engl F Med 1992;326:807-11.

37 Freeman SB, May KM, Pettay D, Fernhoff PM, Hassold TJ. Paternal uniparental disomy in a child with a balanced 15;15 translocation and Angelman syndrome. Am f Med Genet 1993;45:625-30

38 Robinson WP, Wagstaff J, Bernasconi F, Baccichetti C, Artifoni L, Franzoni E, Suslak L, Shih LY, Aviv H, Schinzel AA. Uniparental disomy explains the occurrence of the Angelman or Prader-Willi syndrome in patients with an additional small inv dup(15) chromosome. 7 Med Genet 1993;30:756-60.

39 Smith A, Deng ZM, Beran R, Woodage T, Trent RJ. Familial unbalanced translocation $\mathrm{t}(8 ; 15)(\mathrm{p} 23.3 ; \mathrm{q} 11)$ with
uniparental disomy in Angelman syndrome. Hum Genet uniparental dis

40 Bottani A, Robinson WP, DeLozier-Blanchet CD, Engel E, Morris MA, Schmitt B, Thun-Hohenstein L, Schinzel A. Angelman syndrome due to paternal uniparental disomy of chromosome 15: a milder phenotype? Am f Med Genet 1994;51:35-40.

41 Gillessen-Kaesbach G, Albrecht B, Passarge E, Horsthemke B. Further patient with Angelman syndrome due to paternal disomy of chromosome 15 and a milder phenotype. $A m$ f Med Genet 1995;56:328-9.

42 Tonk V, Schultz RA, Christian SL, Kubota T, Ledbetter DH, Wilson GN. Robertsonian $(15 \mathrm{q} ; 15 \mathrm{q})$ translocation in a child with Angelman syndrome: evidence of uniparental disomy. Am ₹ Med Genet 1996;66:426-8.

43 Prasad C, Wagstaff J. Genotype and phenotype in Angelman syndrome caused by paternal UPD 15. Am f Med Genet 1997;70:328-9

44 Fridman C, Varela MC, Nicholls RD, Koiffmann CP. Unusual clinical features in an Angelman syndrome patien with uniparental disomy due to a translocation $15 \mathrm{q} 15 \mathrm{q}$. Clin Genet 1998;54:303-8.

45 Fridman C, Santos M, Ferrari I, Koiffmann CP. A further Angelman syndrome patient with UPD15 due to paternal meiosis II nondisjunction. Clin Genet 2000;57:86-7.

46 Smith A, Robson L, Buchholz B. Normal growth in Angelman syndrome due to paternal UPD. Clin Genet 1998;53: 223-5.

47 Dupont JM, Le Tessier D, Rabineau D, Cuisset L, Vasseur C, Jeanpierre M, Delpech M, Pinton F, Ponsot G, Denavit C, Jeanpierre $M$, Delpech $M$, Pinton $F$, Ponsot $G$, Denavit aF. Unexpected Angelman syndrome molecular defect in f Med Genet 1999;36:652-4
48 Gyftodimou J, Karadima G, Pandelia E, Vassilopoulos D, Petersen MB. Angelman syndrome with uniparental disomy due to paternal meiosis II nondisjunction. Clin Genet 1999;55:483-6.

49 Dan B, Boyd SG, Christiaens F, Courtens W, Van Maldergem L, Kahn A. Atypical features in Angelman syndrome due to imprinting defect of uniparental disomy of chromosome 15. Neuropediatrics 2000;31:109-10.

50 Reis A, Dittrich B, Greger V, Buiting K, Lalande M, Gillessen-Kaesbach G, Anvret M, Horsthemke B. Imprinting mutations suggested by abnormal DNA methylation patterns in familial Angelman and Prader-Willi syndromes. Am 7 Hum Genet 1994;54:741-7.

51 Saitoh S, Buiting K, Cassidy SB, Conroy JM, Driscoll DJ, Gabriel JM, Gillessen-Kaesbach G, Glenn CC, Greenswag LR, Horsthemke B, Kondo I, Kuwajima K, Niikawa M, Rogan PK, Schwartz S, Seip J, Williams CA, Nicholls RD. Clinical spectrum and molecular diagnosis of Angelman and Prader-Willi syndrome patients with an imprinting mutation. Am f Med Genet 1997;68:195-206.

52 Ohta T, Buiting K, Kokkonen H, McCandless S, Heeger S, Leisti H, Driscoll DJ, Cassidy SB, Horsthemke B, Nicholls RD. Molecular mechanism of Angelman syndrome in two large families involves an imprinting mutation. Am f Hum Genet 1999;64:385-96.

53 Greger V, Knoll JHM, Wagstaff J, Woolf E, Lieske P, Glatt $\mathrm{H}$, Benn PA, Rosengren SS, Lalande, M. Angelman syndrome associated with an inversion of chromosome 15q11.2q24.3. Am f Hum Genet 1997;60:574-80.

54 Fung DC, Yu B, Cheong KF, Smith A, Trent RJ. UBE3A "mutations" in two unrelated and phenotypically different Angelman syndrome patients. Hum Genet 1998;102:48792.

55 Laan LA, v Haeringen A, Brouwer OF. Angelman syndrome: a review of clinical and genetic aspects. Clin Neurol Neurosurg 1999;101:161-70.

56 Minassian BA, DeLorey TM, Olsen RW, Philippart M, Bronstein Y, Zhang Q, Guerrini R, Van Ness P, Livet MO, Delgado-Escueta AV. Angelman syndrome: correlations between epilepsy phenotypes and genotypes. Ann Neurol 1998;43:485-93.

57 van den Ouweland AM, Bakker PL, Halley DJ, CatsmanBerrevoets CE. Angelman syndrome: AS phenotype correlated with specific EEG pattern may result in a high detection rate of mutations in the UBE3A gene. $\mathcal{f}$ Med Genet 1999;36:723-4.

58 Talis AL, Huibregtse JM, Howley PM. The role of E6AP in the regulation of p53 protein levels in human papillomavirus (HPV)-positive and HPV-negative cells. 7 Biol Chem 1998;273:6439-45

59 Hentze MW, Kulozik AE. A perfect message: RNA surveillance and nonsense-mediated decay. Cell 1999;96:307-10.

60 Frischmeyer PA, Dietz HC. Nonsense-mediated mRNA decay in health and disease. Hum Mol Genet 1999;8:1893900 .

61 Williams CA, Lossie AC, Driscoll DJ. Angelman syndrome: mimicking conditions and phenotypes. Am $\mathcal{F}$ Med Genet 2001;101:59-64

62 Razin A, Cedar H. DNA methylation and genomic imprinting. Cell 1994;77:473-6.

63 Tilghman SM. The sins of the fathers and mothers: genomic imprinting in mammalian development. Cell 1999;96:185-93

64 Kubota T, Aradhya S, Macha M, Smith AC, Surh LC, Satish J, Verp MS, Nee HL, Johnson A, Christian SL, Ledbetter DH. Analysis of parent of origin specific DNA for prenatal diagnosis. $\mathcal{F}$ Med Genet 1996;33:1011-14.

65 Jay P, Rougeulle C, Massacrier A, Moncla A, Mattei MG, Malzac P, Roeckel N, Taviaux S, Lefranc JL, Cau P, Berta $\mathrm{P}$, Lalande $\mathrm{M}$, Muscatelli $\mathrm{F}$. The human necdin gene, NDN, is maternally imprinted and located in the Prader-Willi syndrome chromosomal region. Nat Genet 1997;17:357-61.

66 Jong MT, Gray TA, Ji Y, Glenn CC, Saitoh S, Driscoll DJ, Nicholls RD. A novel imprinted gene, encoding a RING zinc-finger protein, and overlapping antisense transcript in the Prader-Willi syndrome critical region. Hum Mol Genet 1999;8:783-93.

67 Meguro M, Mitsuya K, Nomura N, Kohda M, Kashiwagi A, Nishigaki R, Yoshioka H, Nakao M, Oishi M, Oshimura M. Large-scale evaluation of imprinting status in the PraderWilli syndrome region: an imprinted direct repeat cluster resembling small nucleolar RNA genes. Hum Mol Genet 2001;10:383-94

68 Bird AP, Wolffe AP. Methylation-induced repression - belts, braces, and chromatin. Cell 1999;99:451-4.

69 Huibregtse JM, Scheffner M, Howley PM. Cloning and expression of the cDNA for $E 6-A P$, a protein that mediates the interaction of the human papillomavirus E6 oncoprotein with p53. Mol Col Biol 1993;13:775-84.

70 Jiang YH, Armstrong D, Albrecht U, Atkins CM, Noebels JL, Eichele G, Sweatt JD, Beaudet AL. Mutation of the Angelman ubiquitin ligase in mice causes increased cytoplasmic p53 and deficits of contextual learning and long-term potentiation. Neuron 1998;21:799-811.

71 Beer-Romero P, Glass S, Rolfe M. Antisense targeting of E6AP elevates p53 in HPV-infected cells but not in normal cells. Oncogene 1997;14:595-602.

72 Kumar S, Talis AL, Howley PM. Identification of HHR23A as a substrate for E6-associated protein-mediated ubiquitination. F Biol Chem 1999;274:18785-92. 
73 Oda H, Kumar S, Howley PM. Regulation of the Src family tyrosine kinase Blk through E6AP-mediated ubiquitina-
tion. Proc Natl Acad Sci USA 1999;96:9557-62.

74 Kao WH, Beaudenon SL, Talis AL, Huibregtse JM, Howley PM. Human papillomavirus type $16 \mathrm{E} 6$ induces selfubiquitination of the E6AP ubiquitin-protein ligase. 7 Virol 2000;74:6408-17.

75 Rougeulle C, Cardoso C, Fontes M, Colleaux L, Lalande $M$. An imprinted antisense RNA overlaps UBE3A and a second maternally expressed transcript. Nat Genet 1998;19: 15-16.

76 Herzing LB, Kim SJ, Cook EH Jr, Ledbetter DH. The human aminophospholipid-transporting ATPase gene ATP10C maps adjacent to UBE3A and exhibits similar imprinted expression. Am f Hum Genet 2001;68:1501-5.

77 Meguro M, Kashiwagi A, Mitsuya K, Nakao M, Kondo I, Saitoh S, Oshimura M. A novel maternally expressed gene, ATP10C, encodes a putative aminophospholipid translocase associated with Angelman syndrome. Nat Genet 2001; 28:19-20.

78 Watson P, Black G, Ramsden S, Barrow M, Super M, Kerr $\mathrm{B}$, Clayton-Smith J. Angelman syndrome phenotype associated with mutations in MECP2, a gene encoding a methyl CpG binding protein. F Med Genet 2001;38:224-8.
Imessaoudene B, Bonnefont JP, Royer G, Cormier-Daire V,

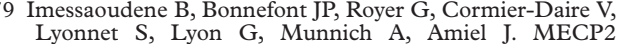
mutation in non-fatal, non-progressive encephalopathy in a male. $\mathcal{F}$ Med Genet 2001;38:171-4.
80 Spritz RA, Bailin T, Nicholls RD, Lee ST, Park SK, Mascari MJ, Butler MG. Hypopigmentation in the Prader-Willi syndrome correlates with P gene deletion but not with haplotype of the hemizygous P allele. Am $\mathcal{F}$ Med Genet 1997;71:57-62.

81 Nicholls RD, Saitoh S, Horsthemke B. Imprinting in Prader-Willi and Angelman syndromes. Trends Genet 1998; 14:194-200

82 Moore T, Haig D. Genomic imprinting in mammalian development: a parental tug-of-war. Trends Genet 1991;7: 45-9.

83 Cattanach BM, Barr JA, Beechey CV, Martin J, Noebels J, Jones J. A candidate model for Angelman syndrome in the mouse. Mamm Genome 1997;8:472-8.

84 Gabriel JM, Merchant M, Ohta T, Ji Y, Caldwell RG, Ramsey MJ, Tucker JD, Longnecker R, Nicholls RD. A transgene insertion creating a heritable chromosome deletion mouse model of Prader-Willi and Angelman syndromes. Proc Natl Acad Sci USA 1999;96:9258-63.

85 Dhar M, Webb LS, Smith L, Hauser L, Johnson D, West DB. A novel ATPase on mouse chromosome 7 is a candidate gene for increased body fat. Physiol Genomics 2000;4:93-100.

86 Johnson DK, Stubbs LJ, Culiat CT, Montgomery CS, Russell LB, Rinchik EM. Molecular analysis of 36 mutations at the mouse pink-eyed dilution (p) locus. Genetics 1995;141: $1563-71$ 